\title{
The Impact of Low-FODMAPs, Gluten-Free, and Ketogenic Diets on Gut Microbiota Modulation in Pathological Conditions
}

\author{
Sofia Reddel ${ }^{1}$, Lorenza Putignani ${ }^{1,2}$ a and Federica Del Chierico ${ }^{1, * \mathbb{D}}$ \\ 1 Human Microbiome Unit, Bambino Gesù Children's Hospital, IRCCS, 00165 Rome, Italy; \\ sofia.reddel@opbg.net (S.R.); lorenza.putignani@opbg.net (L.P.) \\ 2 Parasitology Unit, Bambino Gesù Children's Hospital, IRCCS, 00165 Rome, Italy \\ * Correspondence: federica.delchierico@opbg.net; Tel.: +39-0668594061
}

Received: 15 January 2019; Accepted: 5 February 2019; Published: 12 February 2019

\begin{abstract}
The gut microbiota performs several essential protective, structural, and metabolic functions for host health. The maintenance of a beneficial microbiota requires a homeostatic equilibrium within microbial communities, and between the microorganisms and the host. The gut microbiota composition may be affected by external factors, among them diet habits may be considered most important. In some pathological conditions such as irritable bowel syndrome (IBS), celiac disease (CD), or neurological disorders (ND), specific dietary regimens as low-fermentable, oligo-, di-, mono-saccharides and polyols (FODMAPs), ketogenic (KD), and gluten-free (GFD) diets are considered therapeutic. These kinds of diets are characterized by a reduction or exclusion of a specific nutrient from the entire dietary pattern. Despite these alimentary regimens showing beneficial effects on disease symptoms, they can affect microbiota composition, especially if they are protracted for a long time. To date, only a few studies have reported the effects of these diets on gut microbiota. In this review, we discuss the effects of low-FODMAPs, KD, and GFD on gut microbiota modulation in pathological conditions, advancing the possibility of depicting a balanced diet and developing personalized dietary intervention protocols.
\end{abstract}

Keywords: microbiota; dietary patterns; low-FODMAPs diet; ketogenic diet; gluten-free diet

\section{Introduction}

Microbiota science has flourished in recent decades, and the exciting findings have led to reconsidering the role of the huge number of microorganisms that inhabit the human body and in particular the gastrointestinal (GI) tract. In fact, the gut microbiota performs several essential protective, structural, and metabolic functions for host health. A main function of the microbiota is to inhibit pathogen colonization via several mechanisms, which include direct competition for nutrients, production of antimicrobial molecules and modulation of host immune responses [1]. Gut microbiota has the metabolic capacity to produce and regulate multiple compounds that reach the blood circulation and influence the function of distal organs and systems [2], with specific members that can respond to hormones secreted by the host [3]. Then, for its ability to influence organs and, in turn, to be responsive to the secretions of other host organs, microbiota gains the definition of an organ [4]. Particularly, the microbiota provides host with unique and specific enzymes and biochemical pathways [5]. A large proportion of these metabolic processes are beneficial to the host and are involved in either nutrient acquisition or xenobiotic processing, including the metabolism of undigested carbohydrates and vitamin biosynthesis [5].

The maintenance of a beneficial microbiota requires a homeostatic equilibrium within microbial communities, and between the microorganisms and the host. Failure to achieve or maintain this 
complex homeostasis, called eubiosis, has led to negative consequences on health, causing intestinal diseases and/or disorders, by a dysbiosis framework of gut microbiota.

The gut microbiota composition may be affected by several factors, among them dietary habits may be considered the most important [6]. Indeed, several studies have investigated nutrients and dietary pattern effects on the gut microbiome under physiological conditions [7].

Nevertheless, distinct dietary regimens in specific pathological conditions, such as irritable bowel syndrome (IBS), celiac disease (CD), or neurological disorders (ND) are considered necessary or adjuvant treatments for patients [8-10]. Particularly, low-fermentable, oligo-, di-, mono-saccharides and polyols (FODMAPs) diet, gluten-free diet (GFD) and ketogenic diet (KD) are recommended for IBS, CD, and epilepsy, respectively. These diets are characterized by a reduction or exclusion of a specific nutrient from the entire dietary pattern. In particular, in low-FODMAPs diet, poorly absorbed or indigestible short-chain carbohydrates are reduced; in KD, carbohydrates are reduced; and in GFD, gluten is excluded. Despite these alimentary regimens showing beneficial effects on disease symptoms, they can affect microbiota composition, especially if they are protracted. In fact, the availability of distinct food components favors the selective enrichment of microorganisms capable of exploiting these nutrients and supports microbial metabolic cross-feeding, leading to the maintenance of a microbiota eubiosis [11,12].

The identification of specific eubiotic or dysbiotic profiles under a diet therapy during a specific disease are necessary to develop personalized dietary intervention protocols for patients.

In this review, we highlight the effects of low-FODMAPs diet, KD and GFD, on gut microbiota, in the context of IBS, CD, or ND, also discussing the possibility of restoring eubiotic conditions by probiotic supplementation.

\section{IBS and Low-FODMAPs Dietary Patterns}

IBS is one of the most common functional bowel disorders, characterized by abdominal pain and bloating $[13,14]$. The etiology is unknown, but the pathogenesis seems to be related to all systems included in bowel function regulation: central nervous, enteric nervous, enteroendocrine, gut immune systems, and the gut microbiota [15]. The study of the interplay between diet, host metabolism function, and gut microbiota could help to further understand the complex pathogenesis of this disorder [16,17].

Foods considered as possible etiopathogenetic and/or exacerbating factors of GI disorders are receiving growing attention in the recent scientific literature, with special focus on molecules present in various food classes that would seem to worsen IBS symptoms. These substances, indicated by the term FODMAP, include short-chain fermentable carbohydrates such as lactose, fructose, fructans, galactans, and polyalcohols (sorbitol, mannitol, maltitol, xylitol, and isomalt). These small and osmotically active carbohydrates are poorly absorbed in the small intestine for a slow transport mechanism or an ineffective/reduced enzymatic activity and are rapidly fermented by the colonic microbiota [18]. One of the mechanisms by which FODMAPs exacerbate GI symptoms in IBS is the increasing of water in the small intestine that leads to abdominal pain and bloating [19].

Moreover, FODMAPs bacterial fermentation produces colonic gases, including hydrogen and methane, resulting in luminal distension, and then in triggering IBS symptoms, specifically in those with visceral hypersensitivity $[20,21]$. Furthermore, FODMAPs are implicated in intestinal motility and in alteration of colonic volume [22].

Many clinical studies have examined the effectiveness of a dietary restriction of FODMAPs on IBS symptoms. To date, clinical trials suggest that patients with IBS report symptomatic benefit from a low-FODMAP diet [23-25].

Based on this, a low-FODMAPs diet is now a widely used dietary pattern in managing IBS [18]. The dietary advice consists of the reduction of FODMAPs daily intake from 15-30 g/day (that is generally detected in the usual diet of IBS patients), to 5-18 g/day during the FODMAPs diet [25]. The diet consists of a 4-8-week restriction, followed by a graded FODMAPs reintroduction to determine tolerance [25]. 


\section{Low-FODMAPs Dietary Pattern and Its Impact on Gut Microbiota in IBS}

Despite the demonstrated benefic effects, low-FODMAPs diet has generated concerns as it can lead to an undesired modulation of gut microbiota, which has been implicated in the pathogenesis of IBS [18]. Particularly, IBS patients has been shown to have a dysbiotic microbiota [26] and further alteration of microbiota through FODMAPs restriction diet might predispose the patient to additional pathological dysbiosis.

In a randomized controlled trial, microbiota of IBS patients submitted to 4-week dietary intervention was compared with that of an IBS patient with a habitual diet. The authors demonstrated a reduction in concentration and proportion of luminal Bifidobacteria after the carbohydrate restriction [27]. Levels of total bacteria and the amount of Bacteroides, Prevotella, Eubacterium rectale, Clostridium coccoides, Faecalibacterium prausnitzii, Lactobacillus and Enterococcus remain unchanged after the intervention [27]. Reduction of Bifidobacteria levels as a consequence of a low-FODMAPs diet were also described in recent randomized controlled trials [24,28,29]. Particularly, in the study of Halmos and colleagues, the intake of FODMAPs was very low if compared with the other trials, resulting in a broader gut microbiota alteration. In fact, besides a decrease of Bifidobacteria, a $47 \%$ reduction of total bacterial load and of F. prausnitzii and Clostridium Cluster IV levels were also observed [28].

In a McIntosh study [29], IBS patients were randomized to a low- (LFD) or high-FODMAP diet (HFD) for 3 weeks. Despite a decrease in Bifidobacteria amounts, an increase in Actinobacteria richness and diversity was registered in the LFD group, compared to the HFD group. The latter was also characterized by a decrease of Firmicutes and Clostridiales levels and by a reduction in microbiota overall diversity [29]. On the contrary, a small uncontrolled study revealed no changes in bacterial species richness and in taxa distribution in gut microbiota of IBS children following a low-FODMAPs diet for a week [30].

Interestingly, two studies have investigated the role of the microbiota as a predictor of symptomatic response to the low-FODMAPs diet [17,31]. In a crossover feeding study focused on IBS children, responders patients were enriched in Bacteroides, Ruminococcaceae, F. prausnitzii and in metabolic pathways related to carbohydrate metabolism [31].

These results suggest that patients with a microbiota characterized by a saccharolytic metabolic capacity may receive a major benefit from a low-FODMAPs diet. Moreover, in a very recent paper, Valeur et al. suggested that pre-intervention levels of specific gut microbiota biomarkers as $B$. fragilis, Acinetobacter, Ruminiclostridium, Streptococcus, and Eubacterium may be associated with higher favorable response to a low-FODMAPs diet. These biomarkers were incorporated into a score scheme and subsequently transformed in a response index that could be a useful tool in disease management [17].

Interestingly, also patients with Non-Celiac Gluten Sensitivity (NCGS) seem to benefit from a low-FODMAPs diet with an improvement of gastrointestinal symptoms [32]. However, in these patients a reduction of beneficial Bifidobacteriaceae and an increase of Lachnospiraceae were observed in their gut microbiota [32] (Table 1). 
Table 1. Main findings related to the effect of low-FODMAPs diet (LFD) on gut microbiota in irritable bowel syndrome (IBS) and Non-Celiac Gluten Sensitivity.

\begin{tabular}{|c|c|c|c|c|c|c|c|c|}
\hline$N$ of Subjects & Age of Subjects & Population & $\begin{array}{c}\text { Time of } \\
\text { Administration }\end{array}$ & Methodology & LFD & Findings & Year & Authors \\
\hline $\begin{array}{l}19 \text { IBS patients on } \\
\text { LFD and } 22 \text { IBS } \\
\text { patient on } \\
\text { habitual diet }\end{array}$ & $18-65$ years & IBS & 4 weeks & FISH & $\begin{array}{l}\text { restriction of foods high in fructans } \\
\text { (e.g., wheat products, onions), } \\
\text { GOS (e.g., legumes), polyols (e.g., } \\
\text { pear, sugar-free gums), lactose } \\
\text { (e.g., mammalian milk), and excess } \\
\text { fructose (e.g., honey) }\end{array}$ & $\begin{array}{l}\downarrow \text { Bifidobacteria in LFD versus } \\
\text { habitual. No differences in levels of } \\
\text { total bacteria, Bacteroides Prevotella, E. } \\
\text { rectale-C. coccoides, F. prausnitzii, } \\
\text { Lactobacillus and Enterococcus after LFD }\end{array}$ & 2012 & Staudacher [27] \\
\hline $\begin{array}{l}51 \text { IBS patients on } \\
\text { LFD and } 53 \text { IBS } \\
\text { patients on } \\
\text { Sham diet }\end{array}$ & 18-65 years & IBS & 4 weeks & $\begin{array}{l}\text { qPCR and } 16 \mathrm{~S} \\
\text { rRNA-Illumina } \\
\text { sequencing }\end{array}$ & $\begin{array}{l}\text { restriction of foods high in fructans } \\
\text { (e.g., wheat products, onions), } \\
\text { GOS (e.g., legumes), polyols (e.g., } \\
\text { pear, sugar-free gums), lactose } \\
\text { (e.g., mammalian milk), and excess } \\
\text { fructose (e.g., honey) }\end{array}$ & $\begin{array}{c}\downarrow \text { Bifidobacterium spp. in LFD } \\
\text { versus sham }\end{array}$ & 2017 & Staudacher [24] \\
\hline $\begin{array}{l}37 \text { IBS patients: } 19 \\
\text { on LFD, } 18 \text { on } \\
\text { high FODMAPs } \\
\text { (HFD) }\end{array}$ & $\begin{array}{l}\text { LFD group, } 50.3 \\
\text { median age (years) } \\
\text { HFD group, } 51.5 \\
\text { median age (years) }\end{array}$ & IBS & 3 weeks & $\begin{array}{l}16 \mathrm{~S} \\
\text { rRNA-Illumina } \\
\text { sequencing }\end{array}$ & $\begin{array}{l}\text { restriction of foods high in fructans } \\
\text { (e.g., wheat products, onions), } \\
\text { GOS (e.g., legumes), polyols (e.g., } \\
\text { pear, sugar-free gums), lactose } \\
\text { (e.g., mammalian milk), and excess } \\
\text { fructose (e.g., honey) }\end{array}$ & $\begin{array}{c}\uparrow \text { Actinobacteria, Firmicutes, } \\
\text { Clostridiales; } \uparrow \text { ecological diversity in } \\
\text { LFD versus HFD; } \uparrow \text { Clostridiales XIII } \\
\text { Incertae sedis spp. In addition, } \\
\text { Porphyromonas spp. in LFD versus } \\
\text { baseline; } \downarrow \text { Propionibacteriaceae and } \\
\text { Bifidobacteria in LFD versus baseline }\end{array}$ & 2017 & McIntosh [29] \\
\hline $\begin{array}{l}30 \text { IBS } \\
\text { randomized to } \\
\text { LFD and habitual } \\
\text { Australian diet } \\
\text { and } 8 \text { healthy } \\
\text { individuals } \\
\end{array}$ & $\begin{array}{l}\text { IBS } 41 \text { median age } \\
\text { (years) CTRL } 31 \\
\text { median age (years) }\end{array}$ & IBS & 3 weeks & qPCR & $\begin{array}{l}\text { LFD: } 3.05 \mathrm{~g} \text { (mean value) total } \\
\text { FODMAPs. Habitual diet: } 23.7 \\
\text { (mean value) total FODMAPs }\end{array}$ & $\begin{array}{c}\downarrow \text { Bifidobacteria, F. prausnitzii, } \\
\text { Clostridium cluster IV A. muciniphila, } \\
\text { total bacteria in LFD versus habitual } \\
\text { diet; } \uparrow \text { Clostridium cluster XIV } \\
\text { diversity in LFD versus habitual diet }\end{array}$ & 2014 & Halmos [28] \\
\hline 12 IBS patients & $\begin{array}{l}10.9 \text { median age } \\
\text { (years) }\end{array}$ & IBS & 1 week & $\begin{array}{c}\text { 16S rRNA } 454 \\
\text { pyrosequencing }\end{array}$ & $\begin{array}{l}\text { restriction of foods high in fructans } \\
\text { (e.g., wheat products, onions), } \\
\text { GOS (e.g., legumes), polyols (e.g., } \\
\text { pear, sugar-free gums), lactose } \\
\text { (e.g., mammalian milk), and excess } \\
\text { fructose (e.g., honey) }\end{array}$ & $\begin{array}{l}\text { No changes in terms of richness of } \\
\text { specie and in the taxa composition } \\
\text { after LFD }\end{array}$ & 2014 & Chumpitazi [30] \\
\hline
\end{tabular}


Table 1. Cont.

\begin{tabular}{|c|c|c|c|c|c|c|c|c|}
\hline$N$ of Subjects & Age of Subjects & Population & $\begin{array}{c}\text { Time of } \\
\text { Administration }\end{array}$ & Methodology & LFD & Findings & Year & Authors \\
\hline $\begin{array}{l}33 \text { IBS children } \\
\text { randomized to } \\
\text { LFD (16) or } \\
\text { habitual } \\
\text { American diet (17) }\end{array}$ & $7-17$ years & IBS & 4 days & $\begin{array}{c}16 \mathrm{~S} \text { rRNA } 454 \\
\text { pyrosequencing }\end{array}$ & $\begin{array}{l}\text { The low-FODMAP diet contained } \\
0.15 \mathrm{~g} / \mathrm{kg} \text { * day (maximum } 9 \\
\mathrm{~g} / \text { day) of FODMAPs. The habitual } \\
\text { diet contained } 0.7 \mathrm{~g} / \mathrm{kg} * \text { day } \\
\text { (maximum } 50 \mathrm{~g} / \mathrm{day} \text { ) of } \\
\text { FODMAPs }\end{array}$ & $\begin{array}{l}\uparrow \text { Bacteroides, Ruminococcaceae, } F \text {. } \\
\text { prausnitzii and Erysipelotrichaceae in } \\
\text { responder patients at baseline }\end{array}$ & 2015 & Chumpitazi [31] \\
\hline $\begin{array}{l}61 \text { IBS patients }(32 \\
\text { responders and } 29 \\
\text { non-responders) }\end{array}$ & $\begin{array}{l}\text { Responders } 32.5 \\
\text { median age (years) } \\
\text { non-responders } 39 \\
\text { median age (years) }\end{array}$ & IBS & 4 weeks & $\begin{array}{c}\text { GA-map }{ }^{\mathrm{TM}} \\
\text { Dysbiosis Test }\end{array}$ & $\begin{array}{l}\text { restriction of foods high in fructans } \\
\text { (e.g., wheat products, onions), } \\
\text { GOS (e.g., legumes), polyols (e.g., } \\
\text { pear, sugar-free gums), lactose } \\
\text { (e.g., mammalian milk), and excess } \\
\text { fructose (e.g., honey) }\end{array}$ & $\begin{array}{c}\uparrow \text { P. fragilis, Acinetobacter, } \\
\text { Ruminiclostridium Streptococcus, } \\
\text { Eubacterium in responders versus } \\
\text { non-responders at baseline; } \downarrow \\
\text { Clostridia, Negativicutes, Bacilli } \\
\text { Actinomycetales, Anaerotruncus, } \\
\text { Clostridiales Shigella, Escherichia in } \\
\text { non-responders versus responders } \\
\text { at baseline }\end{array}$ & 2018 & Valeur [17] \\
\hline $\begin{array}{l}19 \text { NCGS patients } \\
10 \text { CTRL }\end{array}$ & $\begin{array}{l}\text { NCGS } 33.8 \text { median } \\
\text { age (years) healthy } \\
\text { controls } 32.8 \\
\text { median age (years) }\end{array}$ & NCGS & $\begin{array}{l}2 \text { weeks LFD } \\
\text { Followed by } 2 \\
\text { weeks GFD }\end{array}$ & $\begin{array}{l}16 \mathrm{~S} \\
\text { rRNA-Illumina } \\
\text { sequencing }\end{array}$ & $\begin{array}{l}\text { LFD in healthy individuals: } 0.98 \\
\text { g/day lactose, } 0.87 \mathrm{~g} / \text { day maltose, } \\
0.22 \mathrm{~g} / \text { day sorbitol LFD in NCGS: } \\
1.10 \mathrm{~g} / \text { day lactose, } 10.83 \text { fructose, } \\
0.73 \mathrm{~g} / \text { day, } 0.12 \mathrm{~g} / \text { day sorbitol }\end{array}$ & $\begin{array}{c}\text { GFD: } \uparrow \text { Bacteroidaceae } \downarrow \\
\text { Lachnospiraceae; LFD: } \\
\downarrow \text { Bifidobacteriaceae } \uparrow \text { Lachnospiraceae }\end{array}$ & 2018 & Dieterich [32] \\
\hline
\end{tabular}

List of abbreviations in alphabetical order: CTRL, controls; FISH, fluorescence in situ hybridization; FODMAP, fermentable, oligo-, di-, mono-saccharides and polyols; GFD, gluten-free diet; GOS, Galacto-oligosaccharides; IBS, irritable bowel syndrome; LFD, low-FODMAPs diet; NCGS, Nonceliac gluten sensitivity; qPCR, quantitative polymerase chain reaction. Bacterial increase: $\uparrow$; bacterial reduction: $\downarrow$. 
Evidence from the literature, therefore, suggests that the low-FODMAPs diet provokes marked shifts on taxonomic gut microbiota composition. However, larger studies are needed to further understand if these alterations are detrimental for health and if these effects persist for a long time.

Supplementation of the diet with probiotics could help in maintaining the beneficial component of gut microbiota, especially considering the inverse correlation between Bifidobacteria and the symptomatology of IBS [33]; however, to date there is not sufficient knowledge for choosing the optimal probiotic strain, dose, and treatment timing.

\section{GFD and CD}

$\mathrm{CD}$ is a frequent chronic inflammatory enteropathy whose clinical framework is various. Symptoms can be intestinal or extra-intestinal and range from acute or chronic diarrhea, abdominal pain, anemia, weight loss up to changes in mood and behavior, and skin disorders [34].

Genetic predisposition (HLA-DQ2 and DQ8 haplotypes) and exposure to gluten prolamines (i.e., gliadin) are involved in the intricate pathogenesis of $\mathrm{CD}$ [35]. Gluten triggers the activation of both innate and adaptive immunity mechanisms [36,37], causing the production of different cytokines and chemokines, responsible for the remodeling and destruction of the intestinal mucosa, finally resulting in villi atrophy [38].

In particular, gliadin peptides are deamidated in the intestinal lamina propria by the tissue transglutaminase and bind the HLA class II DQ2/8 molecules of the antigen-presenting cells [35]. The gliadin peptides are responsible for the activation of the $\mathrm{T}$ cells, macrophages and dendritic cells, with a consequent secretion of inflammatory cytokines [39-41]. It follows the activation of the adaptive immune response through the production of anti-endomysium, antigliadin, and anti-transglutaminase antibodies by $B$ cells that increase intestinal permeability [36].

For patients with CD, a GFD is the only available therapy [42], which implies the exclusion of dietary wheat, rye, barley, and hybrids such as kamut and triticale, all of which contain gluten. In most patients under GFD there is an improvement in clinical manifestations, tissue lesions, and blood values and a lowering of the risk of developing clinical complications associated with CD [10].

\section{Impact of the GFD on Gut Microbiota Modulation}

It is known that gut microbiota is impaired in $C D$ with a reduction in beneficial species and an increase in potential pathogens [43]. Altered gut microbiota and metabolome could play a secondary role in aggravating $C D$ pathogenesis or other diseases in celiac patients by modifying the host immunity and physiology [44].

Several studies have investigated the effect of a GFD on gut microbiota of CD patients (Table 2). 
Table 2. Main findings related to the effect of gluten-free diet (GFD) on gut microbiota in celiac disease (CD).

\begin{tabular}{|c|c|c|c|c|c|c|c|}
\hline$N$ of Subjects & Age of Subjects & Population & $\begin{array}{c}\text { Time of } \\
\text { Administration }\end{array}$ & Methodology & Findings & Year & Authors \\
\hline 16 patients and 8 healthy & 5 median age (years) & $\mathrm{CD}$ & 2 years & qPCR & $\downarrow$ E. coli and Staphylococcus & 2009 & Collado [45] \\
\hline 30 patients and 8 healthy & 4.9 median age (years) & $\mathrm{CD}$ & $1-2$ years & FISH and flow cytometry & $\begin{array}{l}\uparrow \text { overgrowth of total and } \\
\text { Gram-negative bacteria }\end{array}$ & 2007 & Nadal [46] \\
\hline $\begin{array}{l}8 \text { patients and } 5 \text { healthy } \\
\text { children; } 10 \text { patients and } 5 \\
\text { healthy adults }\end{array}$ & $\begin{array}{l}\text { Children } 5.5 \text { median age } \\
\text { and adults } 26.3 \text { median } \\
\text { age (years) }\end{array}$ & $\mathrm{CD}$ & n.d. & $\begin{array}{l}\text { 16S rRNA-based } \\
\text { metagenomics }\end{array}$ & $\begin{array}{l}\downarrow \text { Streptococcus spp. and } \\
\text { Prevotella spp. }\end{array}$ & 2012 & Nistal [47] \\
\hline 19 patients and 15 healthy & $6-12$ years & $\mathrm{CD}$ & 2 years & PCR-DGGE & $\begin{array}{c}\downarrow \text { Lactobacillus, Enterococcus and } \\
\text { Bifidobacteria; } \uparrow \text { Bacteroides, } \\
\text { Staphylococcus, Salmonella, } \\
\text { Shigella and Klebsiella }\end{array}$ & 2011 & Di Cagno [48] \\
\hline 14 patients and 42 healthy & adults & $\mathrm{CD}$ & at least 2 years & Microbiological culture & $\downarrow$ Bifidobacterium & 2014 & Golfetto [49] \\
\hline 21 patients & $6-12$ years & $\mathrm{CD}$ & 2 years & $\begin{array}{l}\text { PCR-DGGE analysis and } \\
\text { Microbiological culture }\end{array}$ & 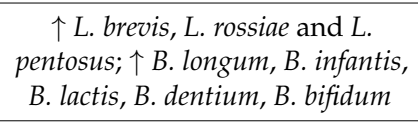 & 2009 & Di Cagno [50] \\
\hline 20 patients and 10 healthy & 11.7 median age (years) & $\mathrm{CD}$ & 9 months & TTGE & $\begin{array}{l}\uparrow \text { B. vulgatus and } \\
\text { C. coccoides group }\end{array}$ & 2010 & Schippa [51] \\
\hline
\end{tabular}

List of abbreviations in alphabetical order: CD, celiac disease; DGGE, denaturing gradient gel electrophoresis analysis; FISH, fluorescent in situ hybridization; GFD, gluten-free diet n.d.: not defined; qPCR, quantitative polymerase chain reaction; TTGE, temporal temperature gradient gel electrophoresis. Bacterial increase: $\uparrow$; bacterial reduction: $\downarrow$. 
Preliminary studies reported that in CD patients, after 2 years of GFD, the imbalance of duodenal mucosal microbiota were not completely restored with a worsening in the reduction of bacterial richness $[45,46]$. In fact, although the relative abundances of some potentially pathogenic bacteria such as Escherichia coli and Staphylococcus decreased after diet, the beneficial species as Bifidobacterium and Lactobacillus levels remained low.

Nistal and colleagues [47] found a decrease in Streptococcus and Prevotella levels in CD patients following a GFD. Moreover, decrease of healthy bacteria such as Lactobacillus, Enterococcus, and Bifidobacteria and increase of detrimental species such as Bacteroides, Staphylococcus, Salmonella, Shigella, and Klebsiella are reported by Di Cagno et al., 2011 [48]. Also in a recent study, a low abundance of Bifidobacterium species was observed in CD patients following a GFD conducted for at least 2 years [49]. Additional support to the indication that a GFD produces a decrease in beneficial bacterial genera including Bifidobacterium and Lactobacillus and an increase of Enterobacteriaceae, responsible for gut inflammation, came from a study of De Palma et al., which explored the effect of a GFD on healthy subjects [52]. The main inference of this study was that a GFD modulate gut microbiota composition regardless of the disease and that this modulation is probably due to the reduction of the polysaccharide intake. The GFD diet is, in fact, characterized by a substantial reduction of fructans, which carry out a prebiotic action [53]. A similar conclusion was drawn in another recent study, in which the effect of GFD on gut microbiota modulation was investigated through a short-term period [54].

Moreover, in another study, Di Cagno and colleagues described that a lower ratio of Bifidobacterium to Bacteroides and Enterobacteria (including E. coli), characteristic of CD patients before diet, still persist under a GFD, confirming the hypothesis that a GFD only partially restores the imbalances of gut microbiota [50]. The same conclusions were also reported by Schippa et al. in a study conducted on children before and after a GFD, in which mucosa-associated microbiota was analyzed [51]. Recently, the importance of individual microbiota predisposition to GFD was highlighted. In this study, a cohort of CD patients with a persistent symptomatology was compared with a cohort of patients without persistent symptoms, both treated with a 3-year GFD [55]. The results indicated that a previous dysbiosis in patients produced a persistency of symptoms, even while adhering to a strict GFD. Particularly, a reduction in gut microbiota diversity, higher levels of Proteobacteria and lower levels of Bacteroidetes and Firmicutes characterized the gut microbiota of patients with persistent symptoms [55].

The most consistent observation across these studies is the inability of GFD to restore gut microbiota dysbiosis of CD patient in terms of Lactobacillus and Bifidobacterium abundances and in some cases to worsen the overall microbiota diversity reduction. The reason is yet not clear; however a hypothesis is that since gluten exerts a prebiotic action, its exclusion in GFD provokes changes in gut microbiota composition also in the absence of disease [53]. For this reason, supplementation of GFD with pre- or probiotics is currently an area of growing interest to improve the clinical management of CD patients under GFD.

\section{Ketogenic Diet (KD) in Neurological Disorders}

The low-carbohydrate, high-fat KD is an effective treatment for epileptic patients that fails in responding to anticonvulsant medications [56]. The efficacy of KD rates, measured in seizure reduction, reaches $50 \%$ in adult intractable epilepsy [57]. Moreover, recently KD had an increase of application in other ND including autism spectrum disorder (ASD), Alzheimer's disease [9], Glucose Transporter 1 Deficiency Syndrome (GLUT1-DS) [58] and multiple sclerosis (MS) [59] and even metabolic syndrome and cancer [9]. The classic KD is based on a ratio of fat to carbohydrate plus protein grams of 3:1 or $4: 1$, which means that $90 \%$ of the energy comes from fat and only $10 \%$ from carbohydrate and protein combined mixture [60]. It induces ketone body production through fat metabolism, with the goal of mimicking a fasting state in the body's tissues, shifting the predominant caloric source from carbohydrate to fat [61]. 
The mechanism of the KD action in epilepsy remains unclear. However, it has been proposed to be related to an involvement in mitochondrial function alterations, effects of ketone bodies on neuronal function and neurotransmitter release, and an antiepileptic effects of fatty acids, and/or glucose stabilization [62].

\section{Impact of KD in Gut Microbiota Modulation}

Different studies investigated the characteristics and composition of intestinal microbiota during a KD (Table 3).

$\mathrm{Ma}$ and co-authors explored the effect of KD on gut microbiome composition and its beneficial effect on neurovascular functions, reducing the risk of neurodegeneration and increased beneficial gut microbiota in young healthy mice [63]. However, the authors described a decreased microbial diversity induced by KD. This is the result of reduced carbohydrate intake, which led to a decrease in polysaccharide content and then to a decrease in many gut microbiota bacteria that produce energy from polysaccharides. Moreover, KD appeared to reduce blood glucose levels and body weight, and to increase blood ketone levels. These effects were correlated with the increase of beneficial bacteria such as Akkermansia muciniphila and Lactobacillus, SCFA producers, and to the reduction of pro-inflammatory taxa such as Desulfovibrio and Turicibacter [63].

The KD altered the composition of the gut microbiota also in mouse model of ASD [64]. In this study, a significant decrease in total bacterial abundance in cecal and fecal matter was reported. However, differently from the previous study, these authors reported a reduction in the A. muciniphila content in mouse microbiota [64].

Olson et al., using two mouse models for refractory epilepsy, revealed the role of gut microbiota in mediating and conferring seizure protection [65]. In fact, the authors demonstrated that the microbiota depletion via high-dose antibiotic treatment raised seizure susceptibility and incidence, in response to the KD. Moreover, the effect of antibiotic treatment resulted annulled by re-colonization with gut bacteria. KD reduced gut microbiota diversity, while increasing the relative abundance of A. muciniphila and Parabacteroides, hence potentially recognized as with a role in seizure protection. Moreover, the authors found that diet- and microbiota-dependent seizure protection was associated with the increase of gamma-aminobutyric acid (GABA) in bulk and glutamate in the hippocampus [65].

A study in children with refractory epilepsy after a week of KD showed a reduction in richness of gut microbiota, also revealing an increment in Bacteroidetes and decrement in Proteobacteria after KD. At genus level, Bacteroides, Bifidobacterium, and Prevotella resulted increased after KD, while Cronobacter diminished. The authors concluded that KD could alleviate seizure frequency in infants with refractory epilepsy and rapidly alter gut microbiota. In fact, the microbiota of epileptic infants differed from that of healthy controls, and after KD therapy changed significantly, with a decrement in pathogens and an increment in beneficial bacteria [66].

In another study, in children affected by refractory epilepsy, after 6 months of treatment with $\mathrm{KD}$, the fecal microbiota profiles showed lower diversity after KD therapy and revealed significantly decreased abundance of Firmicutes and increased levels of Bacteroidetes. In this study, the subjects differently responded to a seizure reduction. In subjects' non-responders after KD, Clostridiales, Ruminococcaceae, Rikenellaceae, Lachnospiraceae, and Alistipes were enriched compared to effective patients. These results suggested that the changes in gut microbiota composition may be associated with different efficacy after KD, and that a specific gut microbiota may serve as an efficiency biomarker and a potential therapeutic target in patients with refractory epilepsy [67]. 
Table 3. Main findings related to the effect of ketogenic diet (KD) on gut microbiota.

\begin{tabular}{|c|c|c|c|c|c|c|c|c|c|}
\hline Subjects/Animals & $N$ of Subjects & Age of Subjects & Population & $\begin{array}{c}\text { Time of } \\
\text { Administration }\end{array}$ & KD & Methodology & Findings & Year & Authors \\
\hline C57BL / 6 male mice & $\begin{array}{l}9-10 \text { for treated } \\
\text { and untreated } \\
\text { groups }\end{array}$ & $\begin{array}{l}12-14 \text { weeks } \\
\text { of age }\end{array}$ & Healthy & 16 weeks & $\begin{array}{c}75.1 \% \text { fat (composed of } \\
\text { saturated, monounsaturated, } \\
\text { and polyunsaturated fatty acids), } \\
8.6 \% \text { protein, } 4.8 \% \text { fiber, } 3.2 \% \\
\text { carbohydrates, } 3 \% \text { ash, and less } \\
\text { than } 10 \% \text { moisture }\end{array}$ & $\begin{array}{c}16 \mathrm{~S} \\
\text { rRNA-based } \\
\text { metagenomics }\end{array}$ & $\begin{array}{c}\downarrow \text { microbiota diversity; } \\
\uparrow \text { Adlercreutzia, Lactobacillus, } \\
\text { Erysipelotrichaceae-Clostridium, } \\
\text { A. muciniphila; } \downarrow \text { Turicibacter, } \\
\text { Clostridiaceae-Clostridium, } \\
\text { Dorea, Desulfovibrio }\end{array}$ & 2017 & Ma [63] \\
\hline $\begin{array}{l}\mathrm{C} 57 \mathrm{BL} / 6 \text { and } \\
\mathrm{BTBR}^{\mathrm{T}+\mathrm{tf} / \mathrm{j}}\end{array}$ & $\begin{array}{l}21 \text { and } 25 \text { per } \\
\text { group }\end{array}$ & 5 weeks of age & ASD & 10-14 days & $75 \% \mathrm{kcal}$ fat & qPCR analysis & $\begin{array}{c}\downarrow \text { bacterial abundance in cecal } \\
\text { and fecal matter; } \downarrow \text { A. } \\
\text { muciniphila, Methanobrevibacter, } \\
\text { and Roseburia in cecal matter; } \downarrow \\
\text { A. muciniphila and Lactobacillus, } \\
\uparrow \text { Enterobacteriaceae in fecal } \\
\text { matter }\end{array}$ & 2016 & Newell [64] \\
\hline $\begin{array}{c}\text { Germ Free } \\
\text { wild-type Swiss } \\
\text { Webster and SPF } \\
\text { C3HeB/FeJ KCNA1 } \\
\text { KO mice }\end{array}$ & $\begin{array}{l}\text { Variable for } \\
\text { each group }\end{array}$ & 3-4-week-old & $\begin{array}{l}\text { 6-Hz-induced } \\
\text { seizure } \\
\text { model of } \\
\text { refractory } \\
\text { epilepsy }\end{array}$ & 3 weeks & 6:1 KD & $\begin{array}{c}16 \mathrm{~S} \\
\text { rRNA-based } \\
\text { metagenomics }\end{array}$ & $\begin{array}{c}\downarrow \text { alpha diversity; } \uparrow A . \\
\text { muciniphila and Parabacteroides }\end{array}$ & 2018 & Olson [65] \\
\hline Human & $\begin{array}{l}14 \text { patients and } \\
30 \text { healthy } \\
\text { controls }\end{array}$ & $\begin{array}{l}1.95 \text { median age } \\
\text { (years) }\end{array}$ & $\begin{array}{l}\text { Refractory } \\
\text { epilepsy }\end{array}$ & 1 week & $\begin{array}{c}\text { Zeneca products: } \\
\text { lipid-to-non-lipid ratio of } 4: 1, \\
\text { with } 60 \% \text { of the total lipid } \\
\text { long-chain triglyceride and } 40 \% \\
\text { medium-chain triglyceride }\end{array}$ & $\begin{array}{c}16 \mathrm{~S} \\
\text { rRNA-based } \\
\text { metagenomics }\end{array}$ & $\begin{array}{c}\downarrow \text { richness of gut bacteria; } \\
\uparrow \text { Bacteroidetes and } \\
\downarrow \text { Proteobacteria; } \uparrow \text { Bacteroides, } \\
\text { Bifidobacterium and Prevotella; } \\
\downarrow \text { Cronobacter }\end{array}$ & 2017 & Xie [66] \\
\hline Human & $\begin{array}{l}20 \text { pre and post } \\
\text { treatment }\end{array}$ & $\begin{array}{l}4.75 \text { median age } \\
\text { (years) }\end{array}$ & $\begin{array}{l}\text { Refractory } \\
\text { epilepsy }\end{array}$ & 6 months & 4:1 ratio $\mathrm{KD}$ & $\begin{array}{c}16 \mathrm{~S} \\
\text { rRNA-based } \\
\text { metagenomics }\end{array}$ & $\begin{array}{c}\downarrow \text { richness of gut bacteria; } \\
\uparrow \text { Bacteroidetes; } \downarrow \text { Firmicutes } \\
\text { and Actinobacteria }\end{array}$ & 2018 & Zhang [67] \\
\hline Human & $\begin{array}{l}25 \text { patients } 14 \\
\text { healthy controls }\end{array}$ & n.d. & $\begin{array}{l}\text { Auto-immune } \\
\text { multiple } \\
\text { sclerosis } \\
\text { (MS) }\end{array}$ & 6 months & $\begin{array}{c}\text { An average daily intake of }<50 \mathrm{~g} \\
\text { carbohydrates, }>160 \mathrm{~g} \text { fat, and } \\
<100 \mathrm{~g} \text { protein was } \\
\text { recommended }\end{array}$ & FISH & $\begin{array}{c}\downarrow \text { total concentration and } \\
\text { diversity of substantial } \\
\text { bacterial groups at week } 2 ; \uparrow \\
\text { total concentration at } 24 \text { weeks }\end{array}$ & 2017 & $\begin{array}{c}\text { Swidsinski } \\
{[68]}\end{array}$ \\
\hline Human & $\begin{array}{l}6 \text { pre and post } \\
\text { treatment }\end{array}$ & $8-34$ years & GLUT1 DS & 3 months & $\begin{array}{l}\text { Starting from } 1: 1 \text { to gradually } \\
\text { proceed to } 2: 1,3: 1 \text { or } 4: 1 \text { ratio } K D\end{array}$ & qPCR analysis & $\uparrow$ Desulfovibrio & 2017 & $\begin{array}{l}\text { Tagliabue } \\
\text { [69] }\end{array}$ \\
\hline
\end{tabular}

List of abbreviations in alphabetical order: ASD, autism spectrum disorder; FISH, fluorescence in situ hybridization; GLUT1 DS, Glucose Transporter 1 Deficiency Syndrome; Hz, Hertz

KD, ketogenic diet; n.d., not defined; qPCR, quantitative polymerase chain reaction. Bacterial increase: $\uparrow$; bacterial reduction: $\downarrow$. 
In the study of Swidsinski and co-workers, the colonic microbiome was investigated in an auto-immune MS cohort of patients during KD treatment [68]. The effects of a KD in the short term produced a reduction of bacterial concentrations and diversity. After 6 months, an inverse effect was registered with a bacterial richness significantly increased and a restoring in bacterial biofermentative functions, markedly impaired in MS patients. Therefore, it appeared that KD normalized concentrations and functions of the colonic microbiome after 6 months of treatment [68].

In GLUT1 DS patients treated with KD for three months a statistically significant increase in Desulfovibrio spp., a sulfite-reducing bacteria, was registered [69]. These effects could be mediated by fat-induced-taurine conjugation of hepatic bile acids, which increases the availability of organic sulfur used by sulfite-reducing microorganisms. Since in the short-term KD treatment the microbiota changing was not accompanied by an amelioration of patient clinical symptoms, the authors suggested that dysbiosis may become important if KDs are consumed for longer periods without supplementing with fermentable substrates, especially considering the potential detrimental effect on gut health of sulfate-reducing bacteria. Therefore, in patients with demonstrated dysbiosis, it may be reasonable to consider a supplementation with pre or probiotics to potentially restore the "ecological balance" of intestinal microbiota [69].

\section{Probiotics Supplementation}

Only a few studies have investigated the supplementation of these dietary patterns with probiotics that could be useful for the recovery and maintenance of a eubiotic gut microbiota.

Particularly, promising evidence comes from studies exploring the effect of a GFD supplemented with probiotics in CD patients [70].

In a recent randomized control trial, Olivares et al. [71] assessed whether the intervention in the gut ecosystem with B. longum CECT 7347 improved the efficacy of the GFD in children with newly diagnosed $C D$. Thirty-three children were randomized to receive a capsule containing the probiotic or placebo daily for 3 months together with a GFD. The coupled intervention with GFD and probiotic led to height percentile increase in terms of growth-related parameters and to a decrease in peripheral CD3+ T lymphocytes number. Interestingly, B. longum CECT 7347 induced a significant decrease of Bacteroides fragilis and Enterobacteriaceae and an increase of harmless to potentially harmful bacteria ratio [71].

In the study of Quagliariello et al. [72] was evaluated the efficacy of 3 months intake of $B$. breve strains B632 and BR03 on 45 CD patients on GFD. The authors demonstrated an increase of Actinobacteria and a restoration of the Firmicutes/Bacteroides ratio, induced by probiotic supplementation, thus re-establishing the eubiosis of CD children under a GFD [72].

The same probiotic strains B. breve B632 and BR03 were administered for three months to 40 children with CD on GFD in another clinical trial, showing a microbiota restoration with an increment in the production of acetic acid and total short-chain fatty acids (SCFAs) [73].

On the contrary, in the study of Harnett et al., based on 45 CD patients under GFD, the supplementation with VSL3 did not produce any differences in the gut microbiota composition and in clinical outcome [74].

Francavilla et al. obtained an improvement in the severity of IBS-type symptoms, in 54 randomized CD patients on strict GFD, receiving for 6 weeks a mixture of 5 strains of lactic acid bacteria and Bifidobacteria: L. casei LMG 101/37 P-17504, L. plantarum CECT 4528, B. animalis subsp. lactis Bi1 LMG P-17502, B. breve Bbr8 LMG P-17501, B. breve B110 LMG P-17500. Particularly, authors observed an increase of presumptive lactic acid bacteria, Staphylococcus and Bifidobacterium in patients receiving probiotic treatment [75].

Moreover, in the only study regarding the supplementation of the low-FODMAPs diet with probiotics, authors administered a multistrain probiotic formulation (Streptococcus thermophilus DSM 24731, B. breve DSM 24732, B. longum DSM 24736, B. infantis DSM 24737, Lactobacillus acidophilus DSM 24735, L. plantarum DSM 24730, L. paracasei DSM 24733, L. delbrueckii subsp. bulgaricus DSM 24734) 
to 27 randomized IBS patients under a 4 weeks low-FODMAPs diet. The authors observed after the probiotic treatment a restoration of Bifidobacterium, always reduced in the gut microbiota of patients under a low-FODMAP diet [24].

Regarding the probiotic treatment coupled to KD, to date there are no reports on this topic.

\section{Conclusions and Future Perspectives}

GFD, low-FODMAPs diet, and KD represent real therapies in distinct pathological conditions. However, many studies have highlighted a pronounced compositional change of the gut microbiota due to these dietary patterns. This side effect seems to be more pronounced in patients under GFD and low-FODMAPs diet, while for KD the picture is not entirely clear. Nevertheless, the data on the effects of long-term GFD on microbiota in CD patients available in the literature are bit dated with respect to the other pathologies.

Considering that gut microbiota has been implicated in the pathogenesis of the diseases here described, its further alteration may have potential consequences for long-term health and might predispose the patient to additional pathological symptoms.

This safety concern constitutes the basis for investigating the supplementation of these diets with probiotics that could be useful for the recovery and maintenance of a eubiotic gut microbiota. For CD and KD, the integration of a GFD and a low-FODMAPs diet with probiotics seems to counteract gut microbiota imbalances and in particular restore Bifidobacterium levels. Regarding KD, some authors suggest that a prolonged KD-induced dysbiosis could raise concern and then supplementation with pre- or probiotics could be recommended.

In conclusion, even if further studies are needed to confirm and/or expand these findings, the evidence collected so far are encouraging and the use of dietary patterns coupled to probiotics could be useful to avoid side effects on health due to the alteration of the intestinal microbiota, especially in pathological subjects already characterized by intestinal dysbiosis.

Author Contributions: Conceptualization, S.R. and F.D.C., Writing-Original Draft Preparation, S.R. and F.D.C., Writing-review \& editing, L.P.

Funding: This work was supported by the Ministry of Health, Ricerca Corrente RC201802P004354 assigned to F.D.C., Children's Hospital Bambino Gesù, IRCCS.

Conflicts of Interest: The authors declare no conflict of interest.

\section{References}

1. Kamada, N.; Seo, S.-U.; Chen, G.Y.; Núñez, G. Role of the gut microbiota in immunity and inflammatory disease. Nat. Rev. Immunol. 2013, 13, 321-335. [CrossRef]

2. Clarke, G.; Stilling, R.M.; Kennedy, P.J.; Stanton, C.; Cryan, J.F.; Dinan, T.G. Minireview: Gut microbiota: The neglected endocrine organ. Mol. Endocrinol. 2014, 28, 1221-1238. [CrossRef] [PubMed]

3. Freestone, P.P.E.; Sandrini, S.M.; Haigh, R.D.; Lyte, M. Microbial endocrinology: How stress influences susceptibility to infection. Trends Microbiol. 2008, 16, 55-64. [CrossRef] [PubMed]

4. Evans, J.M.; Morris, L.S.; Marchesi, J.R. The gut microbiome: The role of a virtual organ in the endocrinology of the host. J. Endocrinol. 2013, 218, R37-R47. [CrossRef] [PubMed]

5. Ursell, L.K.; Knight, R. Xenobiotics and the human gut microbiome: Metatranscriptomics reveal the active players. Cell Metab. 2013, 17, 317-318. [CrossRef]

6. David, L.A.; Maurice, C.F.; Carmody, R.N.; Gootenberg, D.B.; Button, J.E.; Wolfe, B.E.; Ling, A.V.; Devlin, A.S.; Varma, Y.; Fischbach, M.A.; et al. Diet rapidly and reproducibly alters the human gut microbiome. Nature 2014, 505, 559-563. [CrossRef]

7. Sheflin, A.M.; Melby, C.L.; Carbonero, F.; Weir, T.L. Linking dietary patterns with gut microbial composition and function. Gut Microbes 2016, 8, 113-129. [CrossRef]

8. Varjú, P.; Farkas, N.; Hegyi, P.; Garami, A.; Szabó, I.; Illés, A.; Solymár, M.; Vincze, Á.; Balaskó, M.; Pár, G.; et al. Low fermentable oligosaccharides, disaccharides, monosaccharides and polyols (FODMAP) diet 
improves symptoms in adults suffering from irritable bowel syndrome (IBS) compared to standard IBS diet: A meta-analysis of clinical studies. PLOS ONE 2017. [CrossRef]

9. Stafstrom, C.E.; Rho, J.M. The ketogenic diet as a treatment paradigm for diverse neurological disorders. Front. Pharmacol. 2012. [CrossRef]

10. Bascuñán, K.A.; Vespa, M.C.; Araya, M. Celiac disease: Understanding the gluten-free diet. Eur. J. Nutr. 2017, 56, 449-459. [CrossRef]

11. Sonnenburg, J.L.; Bäckhed, F. Diet-microbiota interactions as moderators of human metabolism. Nature 2016, 535, 56-64. [CrossRef] [PubMed]

12. Putignani, L.; Dallapiccola, B. Foodomics as part of the host-microbiota-exposome interplay. J. Proteomics 2016, 147, 3-20. [CrossRef] [PubMed]

13. Gunnarsson, J.; Simrén, M. Efficient diagnosis of suspected functional bowel disorders. Nat. Clin. Pract. Gastroenterol. Hepatol. 2008, 5, 498-507. [CrossRef] [PubMed]

14. Longstreth, G.F.; Thompson, W.G.; Chey, W.D.; Houghton, L.A.; Mearin, F.; Spiller, R.C. Functional bowel disorders. Gastroenterology 2006, 130, 1480-1491. [CrossRef]

15. Enck, P.; Aziz, Q.; Barbara, G.; Farmer, A.D.; Fukudo, S.; Mayer, E.A.; Niesler, B.; Quigley, E.M.M.; Rajilić-Stojanović, M.; Schemann, M.; et al. Irritable bowel syndrome. Nat. Rev. Dis. Primers 2016. [CrossRef] [PubMed]

16. Rajilić-Stojanović, M.; Jonkers, D.M.; Salonen, A.; Hanevik, K.; Raes, J.; Jalanka, J.; de Vos, W.M.; Manichanh, C.; Golic, N.; Enck, P.; et al. Intestinal microbiota and diet in IBS: Causes, consequences, or epiphenomena? Am. J. Gastroenterol. 2015, 110, 278-287. [CrossRef] [PubMed]

17. Valeur, J.; Småstuen, M.C.; Knudsen, T.; Lied, G.A.; Røseth, A.G. Exploring Gut Microbiota Composition as an Indicator of Clinical Response to Dietary FODMAP Restriction in Patients with Irritable Bowel Syndrome. Dig. Dis. Sci. 2018, 63, 429-436. [CrossRef] [PubMed]

18. Barrett, J.S.; Gibson, P.R. Fermentable oligosaccharides, disaccharides, monosaccharides and polyols (FODMAPs) and nonallergic food intolerance: FODMAPs or food chemicals? Therap. Adv. Gastroenterol. 2012, 5, 261-268. [CrossRef]

19. Barrett, J.S.; Gearry, R.B.; Muir, J.G.; Irving, P.M.; Rose, R.; Rosella, O.; Haines, M.L.; Shepherd, S.J.; Gibson, P.R. Dietary poorly absorbed, short-chain carbohydrates increase delivery of water and fermentable substrates to the proximal colon. Aliment. Pharmacol. Ther. 2010, 31, 874-882. [CrossRef]

20. Major, G.; Pritchard, S.; Murray, K.; Alappadan, J.P.; Hoad, C.L.; Marciani, L.; Gowland, P.; Spiller, R. Colon Hypersensitivity to Distension, Rather Than Excessive Gas Production, Produces Carbohydrate-Related Symptoms in Individuals With Irritable Bowel Syndrome. Gastroenterology 2017, 152, 124-133.e2. [CrossRef]

21. Ong, D.K.; Mitchell, S.B.; Barrett, J.S.; Shepherd, S.J.; Irving, P.M.; Biesiekierski, J.R.; Smith, S.; Gibson, P.R.; Muir, J.G. Manipulation of dietary short chain carbohydrates alters the pattern of gas production and genesis of symptoms in irritable bowel syndrome. J. Gastroenterol. Hepatol. 2010, 25, 1366-1373. [CrossRef] [PubMed]

22. Madsen, J.L.; Linnet, J.; Rumessen, J.J. Effect of nonabsorbed amounts of a fructose-sorbitol mixture on small intestinal transit in healthy volunteers. Dig. Dis. Sci. 2006, 51, 147-153. [CrossRef] [PubMed]

23. Staudacher, H.M.; Irving, P.M.; Lomer, M.C.E.; Whelan, K. Mechanisms and efficacy of dietary FODMAP restriction in IBS. Nat. Rev. Gastroenterol. Hepatol. 2014, 11, 256-266. [CrossRef] [PubMed]

24. Staudacher, H.M.; Lomer, M.C.E.; Farquharson, F.M.; Louis, P.; Fava, F.; Franciosi, E.; Scholz, M.; Tuohy, K.M.; Lindsay, J.O.; Irving, P.M.; et al. A Diet Low in FODMAPs Reduces Symptoms in Patients With Irritable Bowel Syndrome and A Probiotic Restores Bifidobacterium Species: A Randomized Controlled Trial. Gastroenterology 2017, 153, 936-947. [CrossRef] [PubMed]

25. Böhn, L.; Störsrud, S.; Liljebo, T.; Collin, L.; Lindfors, P.; Törnblom, H.; Simrén, M. Diet low in FODMAPs reduces symptoms of irritable bowel syndrome as well as traditional dietary advice: A randomized controlled trial. Gastroenterology 2015, 149, 1399-1407.e2. [CrossRef] [PubMed]

26. Simrén, M.; Barbara, G.; Flint, H.J.; Spiegel, B.M.R.; Spiller, R.C.; Vanner, S.; Verdu, E.F.; Whorwell, P.J.; Zoetendal, E.G. Rome Foundation Committee Intestinal microbiota in functional bowel disorders: A Rome foundation report. Gut 2013, 62, 159-176. [CrossRef] [PubMed]

27. Staudacher, H.M.; Lomer, M.C.E.; Anderson, J.L.; Barrett, J.S.; Muir, J.G.; Irving, P.M.; Whelan, K. Fermentable carbohydrate restriction reduces luminal bifidobacteria and gastrointestinal symptoms in patients with irritable bowel syndrome. J. Nutr. 2012, 142, 1510-1518. [CrossRef] 
28. Halmos, E.P.; Christophersen, C.T.; Bird, A.R.; Shepherd, S.J.; Gibson, P.R.; Muir, J.G. Diets that differ in their FODMAP content alter the colonic luminal microenvironment. Gut 2015, 64, 93-100. [CrossRef]

29. McIntosh, K.; Reed, D.E.; Schneider, T.; Dang, F.; Keshteli, A.H.; De Palma, G.; Madsen, K.; Bercik, P.; Vanner, S. FODMAPs alter symptoms and the metabolome of patients with IBS: A randomised controlled trial. Gut 2017, 66, 1241-1251. [CrossRef]

30. Chumpitazi, B.P.; Hollister, E.B.; Oezguen, N.; Tsai, C.M.; McMeans, A.R.; Luna, R.A.; Savidge, T.C.; Versalovic, J.; Shulman, R.J. Gut microbiota influences low fermentable substrate diet efficacy in children with irritable bowel syndrome. Gut Microbes 2014, 5, 165-175. [CrossRef]

31. Chumpitazi, B.P.; Cope, J.L.; Hollister, E.B.; Tsai, C.M.; McMeans, A.R.; Luna, R.A.; Versalovic, J.; Shulman, R.J. Randomised clinical trial: Gut microbiome biomarkers are associated with clinical response to a low FODMAP diet in children with the irritable bowel syndrome. Aliment. Pharmacol. Ther. 2015, 42, 418-427. [CrossRef] [PubMed]

32. Dieterich, W.; Schuppan, D.; Schink, M.; Schwappacher, R.; Wirtz, S.; Agaimy, A.; Neurath, M.F.; Zopf, Y. Influence of low FODMAP and gluten-free diets on disease activity and intestinal microbiota in patients with non-celiac gluten sensitivity. Clin. Nutr. 2018. [CrossRef]

33. Staudacher, H.M.; Whelan, K. Altered gastrointestinal microbiota in irritable bowel syndrome and its modification by diet: Probiotics, prebiotics and the low FODMAP diet. Proc. Nutr. Soc. 2016, 75, 306-318. [CrossRef] [PubMed]

34. Green, P.H.R.; Lebwohl, B.; Greywoode, R. Celiac disease. J. Allergy Clin. Immunol. 2015, 135, 1099-1106, quiz 1107. [CrossRef] [PubMed]

35. Harris, L.A.; Park, J.Y.; Voltaggio, L.; Lam-Himlin, D. Celiac disease: Clinical, endoscopic, and histopathologic review. Gastrointest. Endosc. 2012, 76, 625-640. [CrossRef] [PubMed]

36. Schuppan, D.; Junker, Y.; Barisani, D. Celiac disease: From pathogenesis to novel therapies. Gastroenterology 2009, 137, 1912-1933. [CrossRef]

37. Abadie, V.; Sollid, L.M.; Barreiro, L.B.; Jabri, B. Integration of genetic and immunological insights into a model of celiac disease pathogenesis. Annu. Rev. Immunol. 2011, 29, 493-525. [CrossRef] [PubMed]

38. Dieterich, W.; Esslinger, B.; Schuppan, D. Pathomechanisms in celiac disease. Int. Arch. Allergy Immunol. 2003, 132, 98-108. [CrossRef]

39. Pender, S.L.; Tickle, S.P.; Docherty, A.J.; Howie, D.; Wathen, N.C.; MacDonald, T.T. A major role for matrix metalloproteinases in T cell injury in the gut. J. Immunol. 1997, 158, 1582-1590.

40. Daum, S.; Bauer, U.; Foss, H.D.; Schuppan, D.; Stein, H.; Riecken, E.O.; Ullrich, R. Increased expression of mRNA for matrix metalloproteinases- 1 and -3 and tissue inhibitor of metalloproteinases- 1 in intestinal biopsy specimens from patients with coeliac disease. Gut 1999, 44, 17-25. [CrossRef]

41. Ciccocioppo, R.; Di Sabatino, A.; Bauer, M.; Della Riccia, D.N.; Bizzini, F.; Biagi, F.; Cifone, M.G.; Corazza, G.R.; Schuppan, D. Matrix metalloproteinase pattern in celiac duodenal mucosa. Lab. Invest. 2005, 85, 397-407. [CrossRef] [PubMed]

42. Guandalini, S.; Assiri, A. Celiac disease: A review. JAMA Pediatr. 2014, 168, 272-278. [CrossRef] [PubMed]

43. Marasco, G.; Di Biase, A.R.; Schiumerini, R.; Eusebi, L.H.; Iughetti, L.; Ravaioli, F.; Scaioli, E.; Colecchia, A.; Festi, D. Gut Microbiota and Celiac Disease. Dig. Dis. Sci. 2016, 61, 1461-1472. [CrossRef] [PubMed]

44. De Angelis, M.; Vannini, L.; Di Cagno, R.; Cavallo, N.; Minervini, F.; Francavilla, R.; Ercolini, D.; Gobbetti, M. Salivary and fecal microbiota and metabolome of celiac children under gluten-free diet. Int. J. Food. Microbiol. 2016, 239, 125-132. [CrossRef] [PubMed]

45. Collado, M.C.; Donat, E.; Ribes-Koninckx, C.; Calabuig, M.; Sanz, Y. Specific duodenal and faecal bacterial groups associated with paediatric coeliac disease. J. Clin. Pathol. 2009, 62, 264-269. [CrossRef] [PubMed]

46. Nadal, I.; Donat, E.; Donant, E.; Ribes-Koninckx, C.; Calabuig, M.; Sanz, Y. Imbalance in the composition of the duodenal microbiota of children with coeliac disease. J. Med. Microbiol. 2007, 56, 1669-1674. [CrossRef]

47. Nistal, E.; Caminero, A.; Herrán, A.R.; Arias, L.; Vivas, S.; de Morales, J.M.R.; Calleja, S.; de Miera, L.E.S.; Arroyo, P.; Casqueiro, J. Differences of small intestinal bacteria populations in adults and children with/without celiac disease: Effect of age, gluten diet, and disease. Inflamm. Bowel Dis. 2012, 18, 649-656. [CrossRef]

48. Di Cagno, R.; De Angelis, M.; De Pasquale, I.; Ndagijimana, M.; Vernocchi, P.; Ricciuti, P.; Gagliardi, F.; Laghi, L.; Crecchio, C.; Guerzoni, M.E.; et al. Duodenal and faecal microbiota of celiac children: Molecular, phenotype and metabolome characterization. BMC Microbiol. 2011. [CrossRef] 
49. Golfetto, L.; de Senna, F.D.; Hermes, J.; Beserra, B.T.S.; França, F.; França, F.d.S.; Martinello, F. Lower bifidobacteria counts in adult patients with celiac disease on a gluten-free diet. Arq. Gastroenterol. 2014, 51, 139-143. [CrossRef]

50. Di Cagno, R.; Rizzello, C.G.; Gagliardi, F.; Ricciuti, P.; Ndagijimana, M.; Francavilla, R.; Guerzoni, M.E.; Crecchio, C.; Gobbetti, M.; De Angelis, M. Different fecal microbiotas and volatile organic compounds in treated and untreated children with celiac disease. Appl. Environ. Microbiol. 2009, 75, 3963-3971. [CrossRef]

51. Schippa, S.; Iebba, V.; Barbato, M.; Di Nardo, G.; Totino, V.; Checchi, M.P.; Longhi, C.; Maiella, G.; Cucchiara, S.; Conte, M.P. A distinctive "microbial signature" in celiac pediatric patients. BMC Microbiol. 2010. [CrossRef] [PubMed]

52. De Palma, G.; Collins, S.M.; Bercik, P.; Verdu, E.F. The microbiota-gut-brain axis in gastrointestinal disorders: Stressed bugs, stressed brain or both?: The microbiota-gut-brain axis. J. Physiol. 2014, 592, 2989-2997. [CrossRef] [PubMed]

53. Jackson, F.W. Effects of a gluten-free diet on gut microbiota and immune function in healthy adult human subjects-comment by Jackson. Br. J. Nutr. 2010. [CrossRef] [PubMed]

54. Bonder, M.J.; Tigchelaar, E.F.; Cai, X.; Trynka, G.; Cenit, M.C.; Hrdlickova, B.; Zhong, H.; Vatanen, T.; Gevers, D.; Wijmenga, C.; et al. The influence of a short-term gluten-free diet on the human gut microbiome. Genome Med. 2016. [CrossRef] [PubMed]

55. Wacklin, P.; Laurikka, P.; Lindfors, K.; Collin, P.; Salmi, T.; Lähdeaho, M.-L.; Saavalainen, P.; Mäki, M.; Mättö, J.; Kurppa, K.; et al. Altered duodenal microbiota composition in celiac disease patients suffering from persistent symptoms on a long-term gluten-free diet. Am. J. Gastroenterol. 2014, 109, 1933-1941. [CrossRef] [PubMed]

56. Kwan, P.; Brodie, M.J. Early identification of refractory epilepsy. N. Engl. J. Med. 2000, 342, 314-319. [CrossRef] [PubMed]

57. Williams, T.J.; Cervenka, M.C. The role for ketogenic diets in epilepsy and status epilepticus in adults. Clin. Neurophysiol. Pract. 2017, 2, 154-160. [CrossRef] [PubMed]

58. Klepper, J. GLUT1 deficiency syndrome in clinical practice. Epilepsy Res. 2012, 100, 272-277. [CrossRef] [PubMed]

59. Choi, I.Y.; Piccio, L.; Childress, P.; Bollman, B.; Ghosh, A.; Brandhorst, S.; Suarez, J.; Michalsen, A.; Cross, A.H.; Morgan, T.E.; et al. A Diet Mimicking Fasting Promotes Regeneration and Reduces Autoimmunity and Multiple Sclerosis Symptoms. Cell Rep. 2016, 15, 2136-2146. [CrossRef] [PubMed]

60. Kossoff, E.H.; Zupec-Kania, B.A.; Amark, P.E.; Ballaban-Gil, K.R.; Christina Bergqvist, A.G.; Blackford, R.; Buchhalter, J.R.; Caraballo, R.H.; Helen Cross, J.; Dahlin, M.G.; et al. Optimal clinical management of children receiving the ketogenic diet: Recommendations of the International Ketogenic Diet Study Group: Consensus Statement for the Ketogenic Diet. Epilepsia 2009, 50, 304-317. [CrossRef] [PubMed]

61. Cervenka, M.C.; Kossoff, E.H. Dietary Treatment of Intractable Epilepsy. Continuum 2013, 19, $756-766$. [CrossRef] [PubMed]

62. Lima, P.; Sampaio, L.; Damasceno, N. Neurobiochemical mechanisms of a ketogenic diet in refractory epilepsy. Clinics 2014, 69, 699-705. [CrossRef]

63. Ma, D.; Wang, A.C.; Parikh, I.; Green, S.J.; Hoffman, J.D.; Chlipala, G.; Murphy, M.P.; Sokola, B.S.; Bauer, B.; Hartz, A.M.S.; et al. Ketogenic diet enhances neurovascular function with altered gut microbiome in young healthy mice. Sci. Rep. 2018. [CrossRef] [PubMed]

64. Newell, C.; Bomhof, M.R.; Reimer, R.A.; Hittel, D.S.; Rho, J.M.; Shearer, J. Ketogenic diet modifies the gut microbiota in a murine model of autism spectrum disorder. Mol. Autism 2016. [CrossRef] [PubMed]

65. Olson, C.A.; Vuong, H.E.; Yano, J.M.; Liang, Q.Y.; Nusbaum, D.J.; Hsiao, E.Y. The Gut Microbiota Mediates the Anti-Seizure Effects of the Ketogenic Diet. Cell 2018, 173, 1728-1741.e13. [CrossRef] [PubMed]

66. Xie, G.; Zhou, Q.; Qiu, C.-Z.; Dai, W.-K.; Wang, H.-P.; Li, Y.-H.; Liao, J.-X.; Lu, X.-G.; Lin, S.-F.; Ye, J.-H.; et al. Ketogenic diet poses a significant effect on imbalanced gut microbiota in infants with refractory epilepsy. World J. Gastroenterol. 2017, 23, 6164-6171. [CrossRef] [PubMed]

67. Zhang, Y.; Zhou, S.; Zhou, Y.; Yu, L.; Zhang, L.; Wang, Y. Altered gut microbiome composition in children with refractory epilepsy after ketogenic diet. Epilepsy Res. 2018, 145, 163-168. [CrossRef]

68. Swidsinski, A.; Dörffel, Y.; Loening-Baucke, V.; Gille, C.; Göktas, Ö.; Reißhauer, A.; Neuhaus, J.; Weylandt, K.-H.; Guschin, A.; Bock, M. Reduced Mass and Diversity of the Colonic Microbiome in Patients with Multiple Sclerosis and Their Improvement with Ketogenic Diet. Front. Microbiol. 2017. [CrossRef] 
69. Tagliabue, A.; Ferraris, C.; Uggeri, F.; Trentani, C.; Bertoli, S.; de Giorgis, V.; Veggiotti, P.; Elli, M. Short-term impact of a classical ketogenic diet on gut microbiota in GLUT1 Deficiency Syndrome: A 3-month prospective observational study. Clin. Nutr. ESPEN 2017, 17, 33-37. [CrossRef]

70. Cristofori, F.; Indrio, F.; Miniello, V.L.; De Angelis, M.; Francavilla, R. Probiotics in Celiac Disease. Nutrients 2018, 10, 1824. [CrossRef]

71. Olivares, M.; Castillejo, G.; Varea, V.; Sanz, Y. Double-blind, randomised, placebo-controlled intervention trial to evaluate the effects of Bifidobacterium longum CECT 7347 in children with newly diagnosed coeliac disease. Br. J. Nutr. 2014, 112, 30-40. [CrossRef] [PubMed]

72. Quagliariello, A.; Aloisio, I.; Bozzi Cionci, N.; Luiselli, D.; D'Auria, G.; Martinez-Priego, L.; Pérez-Villarroya, D.; Langerholc, T.; Primec, M.; Mičetić-Turk, D.; et al. Effect of Bifidobacterium breve on the Intestinal Microbiota of Coeliac Children on a Gluten Free Diet: A Pilot Study. Nutrients 2016, 8, 660. [CrossRef] [PubMed]

73. Primec, M.; Klemenak, M.; Di Gioia, D.; Aloisio, I.; Bozzi Cionci, N.; Quagliariello, A.; Gorenjak, M.; Mičetić-Turk, D.; Langerholc, T. Clinical intervention using Bifidobacterium strains in celiac disease children reveals novel microbial modulators of TNF- $\alpha$ and short-chain fatty acids. Clin. Nutr. 2018. [CrossRef] [PubMed]

74. Harnett, J.; Myers, S.P.; Rolfe, M. Probiotics and the Microbiome in Celiac Disease: A Randomised Controlled Trial. Evid. Based Complement. Alternat. Med. 2016. [CrossRef] [PubMed]

75. Francavilla, R.; Piccolo, M.; Francavilla, A.; Polimeno, L.; Semeraro, F.; Cristofori, F.; Castellaneta, S.; Barone, M.; Indrio, F.; Gobbetti, M.; et al. Clinical and Microbiological Effect of a Multispecies Probiotic Supplementation in Celiac Patients With Persistent IBS-type Symptoms: A Randomized, Double-Blind, Placebo-controlled, Multicenter Trial. J. Clin. Gastroenterol. 2018. [CrossRef] [PubMed]

(C) 2019 by the authors. Licensee MDPI, Basel, Switzerland. This article is an open access article distributed under the terms and conditions of the Creative Commons Attribution (CC BY) license (http:// creativecommons.org/licenses/by/4.0/). 